\title{
Analisis Faktor-Faktor yang Berhubungan dengan Kepatuhan ODHA dalam Mengkonsumsi Antiretroviral di Poliklinik VCT RSUP Dr M Djamil Padang Tahun 2017
}

Hamidatul Yuni ${ }^{1}$, Rosfita Rasyid ${ }^{2}$, Dien Gusta Anggraini Nursal ${ }^{1}$

Abstrak

Pasien diindikasikan tidak patuh menggunakan antiretroviral sebanyak 38,5\% di RSUP Dr. M. Djamil Padang. Tujuan: Menentukan faktor-faktor yang berhubungan dengan kepatuhan pasien dalam mengkonsumsi antiretroviral di Poliklinik Voluntary counselling and test RSUP Dr. M. Djamil Padang. Metode: Penelitian ini menggunakan desain mix-method dengan pendekatan kuantitatif cross-sectional, sedangkan pendekatan kualitatif dengan Focus Group Discussion (FGD) dan indepth interview. Hasil: Ada lebih dari separoh Orang Dengan HIV AIDS (ODHA) patuh dalam mengkonsumsi antiretroviral. Ada hubungan yang bermakna antara psikologis pasien dengan kepatuhan ODHA. Dukungan sosial dan efek samping obat ARV tidak berhubungan dengan kepatuhan ODHA. Kejenuhan, hubungan pasien dengan dokter, stigma, layanan konseling pra penggunaan ARV, belum semua ODHA mengenal fasilitas fast track, serta faktor ekonomi menjadi faktor lain yang mempengaruhi kepatuhan ODHA mengkonsumsi ARV. Simpulan: Ada hubungan yang bermakna antara psikologis pasien dengan kepatuhan ODHA.

Kata kunci: antiretroviral, dukungan sosial, efek samping obat, kepatuhan, psikologis pasien

\section{Abstract}

Patients were indicated not adherence to antiretroviral treatment as much as $38.5 \%$ in dr M. Djamil Padang. Objectives: To determined the factors associated with adherence of patients in taking antiretroviral at Poliklinik Voluntary counselling and test RSUP. M. Djamil Padang. Methods: This research was a mix-method with quantitative approach using cross sectional design and qualitative approach with Focus Group Discussion (FGD) and indepth interview. Results: There were more than half of people living with HIV were adherent to taking antiretroviral drugs. There was a significant correlation between the psychological of the patient and the adherence of people living with HIV (PLHIV). Social support and side effects of antiretroviral drugs are not related to PLHIV adherence. Saturation, patient relationship with doctors, stigma, pre-ARV counseling services, not all people living with HIVIAIDS are familiar with fast track facilities, as well as economic factors being another factor influencing PLHIV adherence. Conclusion: There is a significant correlation between the psychological of the patient and the adherence of PLHIV.

Keywords: adherence, antiretroviral, drug side effects, psychological patient, socio support

Affiliasi penulis : ${ }^{1}$ Fakultas Kesehatan Masyarakat, Universitas Andalas,Padang, Indonesia. ${ }^{2}$ Fakultas Kedokteran, Universitas Andalas, Padang, Indonesia.

Korespondensi:Hamidatul Yuni, Email: hamidatulyuni@ph.unand.ac.id Hp. 085363069300

\section{PENDAHULUAN}

Human Imunodeficiency Virus (HIV) adalah virus yang menyerang / menginfeksi sel darah putih yang menyebababkan turunnya kekebalan tubuh manusia.
AIDS atau Acquired Immune Deficiency Syndrome adalah sekumpulan gejala penyakit yang timbul karena turunnya kekebalan tubuh yang disebabkan oleh infeksi HIV. Akibat menurunnya kekebalan tubuh maka orang tersebut sangat mudah terkena berbagai penyakit (infeksi oportunistik) yang sering berakibat fatal ${ }^{1}$.

Pada akhir tahun 2016 di Asia dan Pasifik diketahui bahwa sebanyak 5,1 juta penduduk mengidap HIV, dimana 300 ribu diantaranya merupakan kasus 
baru $^{2}$. Jumlah kasus HIVIAIDS di Indonesia juga mengalami peningkatan, pada tahun 2013 orang dengan HIV sebanyak 29.037, dan AIDS sebanyak 5.608 orang, dengan total orang dengan HIVIAIDS sebanyak 127.427 orang ${ }^{1}$. Jumlah kumulatif kasus HIVIAIDS sejak 1987, HIV 150.296 orang, AIDS 55.799 orang dan totalnya sebanyak 206.095 orang $^{3}$. Hingga akhir Desember tahun 2016 diketahui bahwa jumlah penderita HIV di Indonesia sebanyak 232.323 orang dan AIDS sebanyak 86.725 orang $^{4}$.

Strategi getting to zero yang telah dicanangkan diharapkan dapat menurunkan penularan HIV (infeksi baru) melalui hubungan seksual dan pemakaian narkoba suntik, meningkatkan cakupan pengobatan dengan obat antiretrovirus (ARV) dan layanan pendampingan (care and support), serta meniadakan infeksi HIV baru pada bayi/anak dan menurunkan kematian akibat AIDS pada ibunya ${ }^{5}$.

Pengidap HIV memerlukan pengobatan dengan antiretroviral (ARV) untuk menurunkan jumlah virus HIV didalam tubuh agar tidak masuk kedalam stadium AIDS, sedangkan pengidap AIDS memerlukan pengobatan ARV untuk mencegah terjadinya infeksi oportunistik dengan berbagai komplikasinya. Upaya yang diperlukan untuk menekan kerja virus dengan baik yakni tingkat kepatuhan terapi ARV yang sangat tinggi, setidaknya $95 \%$ dari semua dosis tidak boleh terlupakan. Resiko kegagalan terapi timbul jika pasien sering lupa minum obat. Kerjasama yang baik antara tenaga kesehatan dengan pasien suasana, serta komunikasi yang baik akan membantu pasien untuk patuh minum obat ${ }^{6}$.

Kepatuhan ODHA dalam mengkonsumsi obat diperlukan untuk mencapai keberhasilan pengobatan ARV. Kepatuhan rata-rata pasien pada terapi jangka panjang terhadap penyakit kronis di negara maju sebesar $50 \%$ sedangkan di negara berkembang, jumlah tersebut bahkan lebih rendah. Angka ketidakpatuhan pasien pada terapi antiretroviral diseluruh dunia pada tahun 2001 mencapai 54\% bahkan 2020 diperkirakan akan meningkat lebih dari $65 \%$ hal ini tentunya dapat memberikan efek negatif yang sangat besar ${ }^{7}$. Perkiraan cakupan terapi antiretroviral dibeberapa negara asia tenggara Indonesia 24\%, Malaysia 36\%, Philipine 51\%, Thailand 67\%, dan Kamboja 92\%, Vietnam $52 \%$, Myanmar $24 \%{ }^{8}$.
Akhir Desember 2013 terdapat 1.271 kasus yang ada di Sumatera Barat, yang memenuhi syarat mendapatkan terapi ARV sebanyak 682 orang. Dari 682 orang yang Lost Follow Up (LFU) ada sekitar 14\% pasien yang tidak terpantau, diindikasikan pasien yang tidak patuh menjalankan terapi $\mathrm{ARV}^{9}$.

Rumah Sakit Umum Dr. M. Djamil merupakan salah satu rumah sakit rujukan di Sumatera Barat, pada akhir tahun 2016 jumlah pasien yang positif HIV-AIDS terdapat 1.325 kasus, yang bisa menerima terapi ARV 296 Pasien. Dari 296 pasien yang menerima terapi ARV dipoliklinik khusus Voluntary Counselling and Test (VCT) yang Lost Follow Up (LFU) sebanyak 114 orang. Dilihat dari kunjungan pasien selama 6 bulan terakhir, yang LFU/tidak terpantau ini $38,5 \%$ dan kita indikasikan pasien yang tidak patuh dalam menggunakan ARV ${ }^{10}$.

\section{METODE}

Penelitian ini menggunakan desain mix-methode atau kombinasi pendekatan kuantitatif dan kualitatif. Pengumpulan data dengan menggunakan kuesioner secara kuantitatif, untuk kualiatatif dengan focus group discussion (FGD) dan pertanyaan terbuka untuk memperoleh informasi lebih mendalam mengenai faktor lain yang mempengaruhi kepatuhan penggunaan ARV kepada informan yang dirasa relevan dengan masalah dalam penelitian ini.

Populasi adalah pasien rawat jalan penderita HIVIAIDS di Poliklinik Voluntary Counselling and test (VCT) RSUP Dr M Djamil Padang yang mengkonsumsi obat antiretroviral yaitu sebanyak 296 pasien. Sampel penelitian yang dipilih adalah semua populasi yang memenuhi kriteria inklusi dan kriteria eksklusi sampel sebanyak 59 orang.

Pemilihan informan dalam penelitian dilakukan secara purposive sampling yaitu pemilihan informan yang dianggap mengetahui masalahnya secara lebih luas dan mendalam serta dapat dipercaya sebagai sumber data. Informan terdiri dari 6 orang ODHA, 2 lembaga swadaya masyarakat, 2 pendamping minum obat, dan 2 orang konselor.

Penelitian ini tidak melakukan uji etik karena tidak adanya perlakuan terhadap sampel penelitian atau Orang dengan HIVIAIDS di poliklinik VCT RSUP M. Djamil Padang. 
HASIL

Tabel 1. Karakteristik responden kuantitatif

\begin{tabular}{|c|c|c|}
\hline Karakteristik & Frekuensi & $\%$ \\
\hline \multicolumn{3}{|l|}{ Umur } \\
\hline$\leq 25$ & 12 & 20,3 \\
\hline$>25$ & 47 & 79,7 \\
\hline \multicolumn{3}{|l|}{ Jenis Kelamin } \\
\hline Laki-laki & 46 & 78,0 \\
\hline Wanita & 13 & 22,0 \\
\hline \multicolumn{3}{|l|}{ Pendidikan } \\
\hline Tinggi & 16 & 27,1 \\
\hline Rendah & 43 & 72,9 \\
\hline \multicolumn{3}{|l|}{ Lini Obat } \\
\hline Lini 1 & 56 & 94,9 \\
\hline Lini 2 & 3 & 5,1 \\
\hline \multicolumn{3}{|l|}{ Lama Makan Obat } \\
\hline$<1$ Tahun & 17 & 28,8 \\
\hline 1-3 Tahun & 27 & 45,8 \\
\hline$>3$ Tahun & 15 & 25,4 \\
\hline \multicolumn{3}{|l|}{ Faktor Resiko } \\
\hline Biseksual & 2 & 3,4 \\
\hline IDU & 8 & 13,6 \\
\hline LSL (lelaki suka lelaki) & 26 & 44,0 \\
\hline Pasangan & 24 & 40,6 \\
\hline Transfusi Darah & 3 & 5,0 \\
\hline Tidak Tahu & 9 & 15,3 \\
\hline \multicolumn{3}{|l|}{ Pekerjaan } \\
\hline Pegawai Kontrak & 2 & 3,4 \\
\hline PNS & 2 & 3,4 \\
\hline Swasta & 23 & 39 \\
\hline Mahasiswa & 5 & 8,5 \\
\hline Tani & 1 & 1,7 \\
\hline Tidak Bekerja & 2 & 3,4 \\
\hline Wiraswasta & 13 & 22 \\
\hline Ibu rumah tangga & 11 & 18,6 \\
\hline
\end{tabular}

Pada tabel di atas diketahui sebagian besar responden berumur $>25$ tahun $(79,7)$. Sebagian besar berjenis kelamin laki-laki (78\%). Lebih dari separoh yang memiliki pendidikan Rendah (SD, SMP, SMA) $(72,9 \%)$. Sebagian besar berada pada Lini pertama obat Antiretroviral (94,9\%). ODHA yang mengkonsumsi ARV di VCT hampir separoh 27 orang (45,8\%) yang sudah mengkonsumsi ARV selama 1-3 Tahun.

Persentase faktor resiko tertularnya pasien ODHA di poliklinik VCT RSUP dr. M. Djamil Padang paling tinggi disebabkan karena LSL (lelaki suka lelaki) (44\%). Pekerjaan yang dimiliki ODHA bervariasi ada yang pegawai swasta, PNS, Tani, swasta, wiraswasta, tidak bekerja, bahkan ada Ibu rumah tangga dan mahasiswa, persentase yang terbanyak adalah swasta (39\%).

Tabel 2. Hubungan karakteristik dengan kepatuhan

\begin{tabular}{|c|c|c|c|c|c|c|c|}
\hline \multirow{3}{*}{ Variabel } & \multicolumn{6}{|c|}{ Kepatuhan } & \multirow{3}{*}{ p } \\
\hline & \multicolumn{2}{|c|}{ Rendah } & \multicolumn{2}{|c|}{ Sedang } & \multicolumn{2}{|c|}{ Tinggi } & \\
\hline & $\mathrm{n}$ & $\%$ & $\mathrm{n}$ & $\%$ & $\mathrm{n}$ & $\%$ & \\
\hline$\leq 25$ & 0 & 0 & 5 & 41,7 & 7 & 58,3 & - \\
\hline$>25$ & 5 & 10,6 & 13 & 27,7 & 29 & 61,7 & \\
\hline Jumlah & 5 & 8,5 & 18 & 30,5 & 36 & 36,0 & \\
\hline Wanita & 2 & 15,4 & 5 & 38,5 & 6 & 46,2 & 0,389 \\
\hline Laki- & 3 & 6,5 & 13 & 28,3 & 30 & 65,2 & \\
\hline \multicolumn{8}{|l|}{ laki } \\
\hline Jumlah & 5 & 8,5 & 18 & 30,5 & 36 & 61,0 & \\
\hline Tinggi & 5 & 11,6 & 9 & 20,9 & 29 & 67,4 & - \\
\hline Endah & 0 & 0 & 9 & 56,3 & 7 & 43,8 & \\
\hline Jumlah & 5 & 8,5 & 18 & 30,5 & 36 & 61,0 & \\
\hline Lini 1 & 5 & 8,9 & 17 & 30,4 & 34 & 60,7 & - \\
\hline \multirow[t]{2}{*}{ Lini 2} & 0 & 0 & 1 & 33,3 & 2 & 66,7 & \\
\hline & 5 & 8,5 & 18 & 30,5 & 36 & 36,0 & \\
\hline \multicolumn{8}{|l|}{ Jumlah } \\
\hline$<1$ Tahun & 0 & 0 & 4 & 23,5 & 13 & 76,5 & - \\
\hline 1-3 Tahun & 3 & 11,1 & 7 & 25,9 & 17 & 63,0 & \\
\hline$>3$ Tahun & 2 & 13,3 & 7 & 46,7 & 6 & 40,0 & \\
\hline Jumlah & 5 & 8,5 & 18 & 30,5 & 36 & 61,0 & \\
\hline
\end{tabular}

Hasil analisis hubungan antara jenis kelamin dengan kepatuhan penggunaan ARV diperoleh persentase perempuan yang memiliki kepatuhan tinggi sebanyak $46,2 \%$ dan laki-laki yang memiliki kepatuhan yang tinggi sebanyak 65,2\%. Hasil uji Chi-square diperoleh nilai $p=0,389$ maka dapat disimpulkan tidak ada hubungan yang signifikan antara jenis kelamin dengan kepatuhan ODHA dalam mengkonsumsi ARV.

Hasil uji statistik umur, pendidikan, lini obat, dan lama makan obat dengan kepatuhan tidak dapat digunakan karena ada cell yang memiliki nilai 0 .

Hasil analisis tabel silang antara umur dengan kepatuhan diperoleh persentase ODHA berumur $>25$ tahun memiliki kepatuhan yang tinggi sebanyak $61,7 \%$ lebih besar dari ODHA yang berumur $\leq 25$ tahun sebanyak 58,3\%. ODHA yang memiliki pendidikan tinggi dengan kepatuhan yang tinggi persentasenya sebanyak $67,4 \%$ lebih besar dari ODHA yang memiliki pendidikan rendah sebanyak $43,8 \%$. 
Persentase ODHA yang berada pada lini obat kedua kepatuhan yang tinggi sebanyak $66,7 \%$ lebih besar dari ODHA yang berada pada lini obat pertama sebanyak $60,7 \%$. Persentase lama minum obat dengan kepatuhan penggunan ARV lebih besar pada ODHA yang minum ARV kurang dari setahun memilki kepatuhan yang tinggi sebanyak $76,5 \%$.

Distribusi frekuensi masing-masing variable bisa dilihat pada gambar berikut:

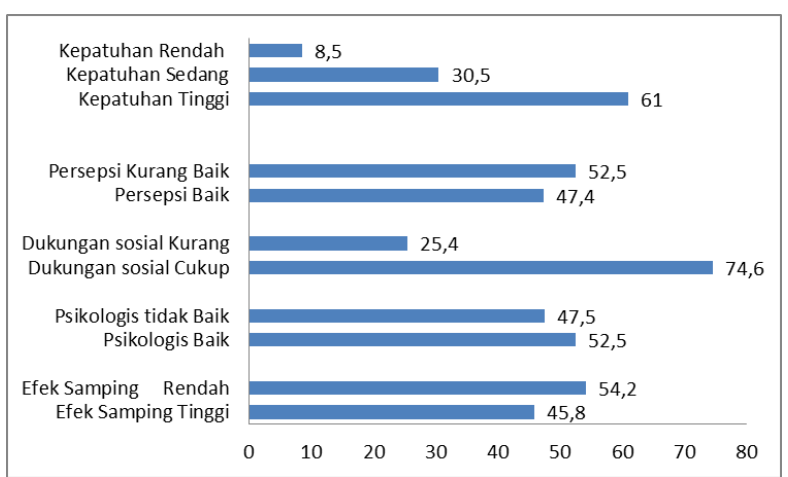

Gambar 1. Distribusi frekuensi variabel

Gambar diatas terlihat bahwa lebih dari separoh ODHA yang memiliki kepatuhan yang tinggi dalam mengkonsumsi obat antiretroviral di poliklinik VCT RSUP Dr. M. Djamil Padang yakni sebanyak 61\%.

Distribusi frekuensi variabel independen terlihat bahwa lebih dari separoh pasien yang memiliki persepsi yang kurang baik tentang obat Antiretroviral yakni sebanyak 52,5\%. Pasien memiliki dukungan sosial yang cukup $74,6 \%$. Sebanyak $47,5 \%$ pasien ODHA di Poliklinik VCT RSUP dr. M. Djamil Padang dengan keadaan psikologis tidak baik Selama seminggu dan sebulan terakhir.

Pasien yang memiliki efek samping yang tinggi hampir separoh yakni sebanyak $45,8 \%$, sebagian kecil (16,9\%) mengalami masalah pada kulit seperti ruam kulit, kering dan gatal sangat mengganggu pasien yang menjalani terapi Antiretroviral.

Pada Tabel 3 diketahui persentase ODHA dengan persepsi yang kurang baik memiliki kepatuhan yang tinggi sebanyak 45,2\% lebih kecil dari ODHA dengan persepsi baik sebanyak 78,6\%. Hasil uji Chi-square tidak bisa digunakan karena ada salah satu cell yang nilainya 0.
Tabel 3. Analisis bivariat variabel independen dengan variabel dependen

\begin{tabular}{|c|c|c|c|c|c|c|c|}
\hline \multirow{3}{*}{ Variabel } & \multicolumn{6}{|c|}{ Kepatuhan } & \multirow{3}{*}{ p } \\
\hline & \multicolumn{2}{|c|}{ Rendah } & \multicolumn{2}{|c|}{ Sedang } & \multicolumn{2}{|c|}{ Tinggi } & \\
\hline & $\mathrm{n}$ & $\%$ & $\mathrm{n}$ & $\%$ & $\mathrm{n}$ & $\%$ & \\
\hline Kurang Baik & 5 & 16,1 & 12 & 38,7 & 14 & 45,2 & - \\
\hline Baik & 0 & 0 & 6 & 21,4 & 22 & 78,6 & \\
\hline Jumlah & 5 & 8,5 & 18 & 30,5 & 36 & 61 & \\
\hline Kurang & 2 & 13,3 & 4 & 26,7 & 9 & 60 & 0,719 \\
\hline Cukup & 3 & 6,8 & 14 & 31,8 & 27 & 61,4 & \\
\hline Jumlah & 5 & 8,5 & 18 & 30,5 & 36 & 61 & \\
\hline Tidak Baik & 2 & 7,1 & 13 & 46,4 & 13 & 46,4 & 0,041 \\
\hline Baik & 3 & 9,7 & 5 & 16,1 & 23 & 74,2 & \\
\hline Jumlah & 5 & 8,5 & 18 & 30,5 & 36 & 61 & \\
\hline Rendah & 2 & 6,3 & 8 & 25 & 22 & 68,8 & 0,409 \\
\hline Tinggi & 3 & 11,1 & 10 & 37 & 14 & 51,9 & \\
\hline Jumlah & 5 & 8,5 & 18 & 30,5 & 36 & 61 & \\
\hline
\end{tabular}

Dukungan sosial dengan kepatuhan ODHA dalam mengkonsumsi ARV yang disajikan pada tabel di atas menunjukkan bahwa persentase ODHA dengan dukungan sosial yang cukup memiliki kepatuhan yang tinggi sebanyak $61,4 \%$ sedikit lebih besar dari ODHA yang memiliki dukungan sosial yang kurang sebanyak $60 \%$. Hasil uji statistik menunjukkan bahwa tidak ada hubungan yang signifikan antara dukungan sosial dengan kepatuhan ODHA dalam mengkonsumsi ARV dengan $p=0,719$.

Analisis hubungan antara psikologis pasien dengan kepatuhan ODHA dalam mengkonsumsi ARV yang disajikan dalam tabel di atas menunjukkan bahwa persentase psikologis pasien yang baik memiliki kepatuhan yang tinggi dalam mengkonsumsi ARV sebanyak $74,2 \%$ lebih besar dari psikologis pasien yang tidak baik yakni sebanyak $46,4 \%$. Hasil uji statistik menunjukkan bahwa ada hubungan yang signifikan antara psikologis pasien dengan kepatuhan ODHA dalam mengkonsumsi ARV di poliklinik VCT RSUP dr. M. Djamil Padang dengan $p=0,041$.

Analisis hubungan antara efek samping obat dengan kepatuhan ODHA dalam mengkonsumsi ARV 
yang disajikan dalam tabel di atas diperoleh persentase ODHA dengan efek samping obat rendah memiliki kepatuhan yang tinggi sebanyak $68,8 \%$ lebih besar dari ODHA dengan efek samping obat yang tinggi $(51,9 \%)$. Hasil uji statistik menunjukkan bahwa tidak ada hubungan yang bermakna antara efek samping obat dengan kepatuhan ODHA dalam mengkonsumsi ARV dengan nilai $p=0,409$.

Berdasarkan hasil FGD dan wawancara mendalam diperoleh informasi mengenai faktor lain yang mempengaruhi kepatuhan ODHA dalam mengkonsumsi ARV yaitu kejenuhan, stigma, stadium klinis, infeksi oportunistik, jarak rumah, jaminan kesehatan ditambah dengan faktor ekonomi, efek samping obat, pasien yang mengkonsumsi obat herbal, hubungan pasien dengan dokter, pola hidup pasien, pekerjaan dan dukungan sosial.

\section{PEMBAHASAN}

Kerja virus perlu dikendalikan dengan terapi ARV, dan kepatuhan terhadap terapi sangat diperlukan untuk pengendalian retro virusnya serta meningkatkan kualitas dan harapan hidup pasien ${ }^{6} .61 \%$ pasien ODHA dalam terapi ARV di RSUP M. Djamil padang memiliki kepatuhan yang tinggi dan sebagian kecil menyatakan sering lupa minum obat $(18,6 \%)$.

Hal ini didukung dari hasil penelitian kualitatif bahwasanya sering lupa disebabkan karena lupa dalam sehari minum obat dan ada yang lupa dalam beberapa jam minum obat. Keadaan tersebut merupakan bentuk ketidakpatuhan pasien dalam mengonsumsi obat anti retroviral. Khusus untuk ARV lini pertama tidak boleh lewat waktu minum obatnya lebih dari 1 (satu) jam, bahkan untuk lini kedua tidak boleh sama sekali terlewat waktunya dari waktu yang seharusnya mengkonsumsi ARV tersebut.

Sejalan dengan penelitian Hansana et al (2013) bahwa ketidakpatuhan dalam terapi ARV karena lupa $(62.2 \%)^{11}$. Lupa meminum obat juga menjadi kendala kepatuhan pada pasien HIV yang sedang terapi ARV di Mangalore, India Selatan ${ }^{12}$.

Anderson et al dalam Horne menjelaskan pasien dapat mengingat kurang dari $50 \%$ informasi dari resep. Hinkin juga dalam Horne mendapatkan kinerja daya ingat berkolerasi dengan penurunan kepatuhan pasien
HIV Hambatan umum untuk kepatuhan adalah sederhana lupa minum obat pada waktu yang ditentukan ${ }^{13}$.

Analisis bivariat kepatuhan hanya berhubungan dengan psikologis pasien ODHA. Pasien memiliki efikasi diri yang baik dalam menghadapi masalah pribadi, dan hanya sebagian kecil $(18,6 \%)$ yang tidak pernah merasa memiliki kemampuan untuk sukses dalam mengahadapi masalah pribadinya.

Penelitian Chesney et al di Amerika Serikat yang menyatakan kepatuhan pasien dengan self efficacy pasien memiliki hubungan yang signifikan ${ }^{14}$. Self efficacy ini merupakan keyakinan yang ada pada diri seseorang yang dapat mengontrol tindakan ${ }^{15}$. Ada tiga bentuk respon emosional yang secara umum yang mungkin muncul pada saat dokter mendiagnosis seseorang menderita penyakit kronis seperti AIDS yaitu penolakan, kecemasan, dan depresi ${ }^{16}$.

Efikasi diri dikaitkan dengan perilaku kesehatan dan kepatuhan pengobatan pada ODHA di Cina menunjukkan bahwa Efikasi diri, kepatuhan pengobatan dan penggunaan obat merupakan prediktor signifikan kualitas hidup ${ }^{17}$. Khotimah et al juga menyatakan kepatuhan terapi ARV dipengaruhi oleh efikasi diri, ODHA yang memiliki efikasi diri yang rendah beresiko tidak patuh7,6 kali lebih besar dibandingkan dengan ODHA yang memiliki efikasi diri yang tinggi ${ }^{18}$.

Ada tiga bentuk respon emosional yang secara umum mungkin muncul pada saat dokter mendiagnosis seseorang menderita penyakit kronis seperti AIDS yaitu penolakan, kecemasan, dan depresi. ${ }^{16}$. Pasien ODHA yang baru mengetahui statusnya memang sering mengalami permasalahan psikologis, namun hal tersebut bisa diatasi dengan bergabung kepada kelompok dukungan sebaya (KDS) yang memberikan motivasi bahwa ODHA masih memiliki kesempatan kedua dengan mengkonsumsi $A R V$, dan kepatuhan pasien menjadi hal yang penting dalam pengobatan antiretroviral.

Nilai Ketuhanan dimiliki oleh setiap masyarakat Indonesia, hal ini perlu dimunculkan kembali sehingga meningkatkan keyakinan pada ODHA karena masih ada peluang untuk mempertahankan kualitas hidup dengan menggunakan obat antiretroviral sesuai anjuran dokter. selain itu ODHA dapat melakukan kegiatan- 
kegiatan yang positif termasuk menyalurkan hobinya, sehingga ODHA juga bisa mempertahankan kesehatan mental dan spiritualnya.

Berdasarkan uji statistik variabel lain tidak berhubungan dengan kepatuhan namun pada tabel silang tersebut dapat kita lihat distribusinya. Sejalan dengan penelitian Lumbanbatu et al bahwa tidak ada hubungan bermakna antara persepsi dengan kepatuhan ODHA dalam menjalani terapi $A R V^{19}$. Distribusi tabel silang persepsi pasien sejalan dengan kepatuhan pasien ODHA dalam mengkonsumsi ARV dimana pasien yang memiliki persepsi baik dengan kepatuhan yang tinggi persentasenya lebih besar $(78,6 \%)$ dari ODHA yang memiliki persepsi yang kurang baik $(45,2 \%)$. Persepsi ODHA dilihat dari distribusi pendidikan, terlihat ODHA yang memiliki pendidikan tinggi dengan kepatuhan tinggi $(67,4 \%)$ lebih besar persentasenya dari ODHA yang berpendidikan rendah $(43,8 \%)$.

Respon tertutup dalam bentuk persepsi akan tergambar dari tindakan pasien dalam mematuhi minum obat ARV. Respon subjektif pasien terhadap lingkungannya membuat pasien memiliki sudut pandang terhadap obat antiretroviral $(A R V)^{20}$.

Selain pendidikan, lingkungan bisa saja menampilkan hal-hal yang positif contohnya jika ODHA memiliki kelompok dukungan sebaya (KDS) yang dapat memberikan informasi-informasi mengenai segala sesuatu yang terkait dengan ARV. Bahkan lebih dari itu KDS juga bisa menampilkan testimoni-testimoni dari ODHA yang bisa bertahan dengan penyakit HIVIAIDS sebagai bentuk dukungan emosional, sehingga nantinya bisa menimbulkan persepsi yang baik tentang ARV.

Dukungan sosial pada ODHA secara statistik tidak memiliki hubungan yang bermakna dengan kepatuhan ODHA dalam mengkonsumsi ARV, hal ini sejalan dengan penelitian yang dilakukan oleh Damulira bahwa dukungan sosial dari pengaruh keluarga tidak berhubungan dengan kepatuhan dalam terapi antiretroviral di Uganda Sejalan ${ }^{21}$. Begitu juga dukungan sosial juga tidak berhubungan dengan ketidak patuhan di KwaZulu Natal, Afrika Selatan ${ }^{22}$.

Dukungan sosial dilihat dari tabel silang terlihat sedikit perbedaan kepatuhan ODHA yang memiliki dukungan sosial yang kurang dengan dukungan sosial yang cukup, disebabkan karena masih ada ODHA yang tidak mendapatkan dukungan dari keluarganya. Pengetahuan keluarga yang masih kurang tentang penyakit HIVIAIDS, menjadi penolakan kepada pasien ODHA dan bahkan ada ODHA yang sudah meninggal dunia kasur dan pakaiannya semua dibakar oleh keluarga.

ODHA juga menyatakan mendapatkan dukungan yang cukup dari pasangan, anggota keluarga, teman bahkan tetangga, dan dari kelompok yang sama-sama pendeita HIVIAIDS yang tergabung dalam sebuah lembaga swadaya masyarakat (LSM) yang bergerak aktif memberikan dukungan terhadap ODHA, dimana salah satu perannya sebagai kelompok dukungan sebaya (KDS). KDS memberikan dampingan kepada ODHA pada saat akan melakukan tes, setelah diketahui statusnya, dampingan pada saat memulai minum ARV yang memungkinkan munculnya efek samping-efek samping yang membuat ODHA menghentikan terapi ARV nya.

Secara statistik efek samping obat dan kepatuhan ODHA memang tidak memilki hubungan, namun dilihat dari tabel bahwa kepatuhan ODHA yang tinggi dengan efek samping yang rendah persentasenya lebih besar dari ODHA yang memiliki efek samping tinggi. Dari hasil FGD dengan ODHA, 4 dari 6 ODHA mengalami efek samping seperti kulit berwarna kehitaman, anemia berat, pusing, berhalusinasi bahkan ada yang mengalami efek samping Stevens Johnson Sindrom. Dari wawancara dengan LSM ada dampingannya yang mengeluhkan efek samping pada saat awal mengkonsumsi ARV, dan memutuskan untuk menghentikan terapi ARV nya. Dilihat dari distribusi pasien yang baru menggunakan obat ARV (< 1 tahun) lebih banyak merasakan efek samping yang tinggi $(64,7 \%)$ dibandingkan dengan yang telah mengkonsumsi ARV 1-3 tahun $(40,7 \%),>3$ tahun $(33,3 \%)$.

ODHA yang melaporkan merasa sehat sebelum memulai terapi ARV, seringkali kurang dapat menoleransi efek samping, dan dalam banyak kasus kejadian ini memicu mereka melepaskan diri dari perawatan $\mathrm{HIV}^{23}$

Pasien yang memutuskan untuk tidak mengkonsumsi antiretroviral ini akan menyebabkan timbulnya keluhan yang menyebabkan pasien datang 
kembali, bahkan ada pasien yang memutus pengobatan selama dua tahun, lalu datang kembali pada saat sudah ada penyakit penyerta. Bisa jadi pasien yang datang kembali bertahan pada obat lini pertama atau sudah harus masuk kepada lini kedua dan seterusnya. Pada saat pasien lini pertama tidak patuh dengan berbagai alasan, tapi lini kedua wajib meningkatkan kepatuhannya dari sebelumnya, karena obat lini kedua tidak ada toleransi waktu minimal seperti yang ada pada lini kedua yang masih ada toleransi waktu satu jam.

Efek samping obat merupakan dampak dari obat yang tidak diinginkan terjadi pada pasien yang menjalani terapi antiretroviral (ARV). Efek samping bisa ringan, sedang bahkan berat yang dialami ODHA diawal-awal mengkonsumsi ARV tersebut. Hal ini sulit untuk dihindari, namun jika ada keluhan pasien ODHA akan melakukan konsultasi kepada dokternya apakah jenis obat ARV ini bisa dilanjutkan atau diganti.

Faktor lain yang menjadi kendala kepatuhan ODHA dalam mengkonsumsi ARV yakni kejenuhan dan stigma. Kejenuhan merupakan perasaan yang berasal dari diri ODHA sendiri. Kejenuhan bisa disebabkan karena pasien belum pernah berada ditaraf AIDS, sudah bosan minum obat yang terus menerus dan seumur hidup. Stigma terhadap pasien ODHA pada masyarakat Indonesia, Sumatera Barat khususnya yang masih menjunjung tinggi nilai-nilai, sehingga HIVIAIDS itu merupakan penyakit negatif. Hal ini dikarenakan karena penyakit ini banyak disebabkan karena perilaku yang menyimpang seperti LSL, IDU, dan berhubungan seksual dengan banyak pasangan.

\section{SIMPULAN}

Ada hubungan yang bermakna antara psikologis pasien dengan kepatuhan ODHA. Dukungan sosial, persepsi dan efek samping tidak berhubungan dengan kepatuhan ODHA. Faktor lain yang mempengaruhi kepatuhan ODHA dalam mengkonsumsi ARV yaitu kejenuhan dan stigma.

\section{SARAN}

Diharapkan Rumah Sakit meningkatkan sosialisasi layanan fast track dan LSM untuk merangkul ODHA yang belum mau ikut dalam pertemuan, serta pasien ODHA diharapkan untuk berkumpul dengan kelompok sebaya dan lebih mendekatkan diri kepada Tuhan Yang Maha Esa serta melakukan kegiatankegiatan yang positif.

\section{DAFTAR PUSTAKA}

1. Kementerian Kesehatan RI. Data situasi dan analisis HIV AIDS. Jakarta; 2014

2. United Nation Program on HIVIAIDS. Global AIDS up to date date. (March). [serial online]. 2016. (diunduh 20 Desember 2016). Tersedia dari: https://www.unaids.org/sites/default/files/media ass et/global-AIDS-update-2016 en.pdf

3. Komisi Penanggulangan AIDS Nasional. Laporan KPAN tahun 2014. Jakarta; 2014

4. Spiritia Y. Laporan situasi perkembangan HIVIAIDS dan PIMS s.d Desember 2016; 2016. (diakses 22 Mar 2017). Tersedia dari: http://spiritia.or.id/Stats/ detailstat.php?no=8

5. United Nation Program on HIVIAIDS. Getting to zero: 2011-2015 strategy joint united programme on HIVIAIDS. 2010 D. (diunduh 2017). Tersedia dari: https://www.unaids.org/sites/default/files/sub landin g/files/JC2034 UNAIDS Strategy en.pdf

6. Kementerian Kesehatan RI. Pedoman Nasional Tatalaksana Klinis Infeksi HIV dan Terapi Antiretroviral pada Orang Dewasa. Jakarta; 2011.

7. Badan Pengawas Obat dan Makanan RI. Info POM. 2006;7(5):1-12.

8. United Nation Program on HIVIAIDS. Global HIVIAIDS response - epidemic update and health sector progress towards universal access progress report 2011. 2011. (diunduh 20 Des 2016). Tersedia dari: https://www.who.int/hiv/pub/ progress report2011/en/

9. Kementerian Kesehatan RI. Laporan situasi perkembangan HIV\&AIDS di Indonesia 2013. Jakarta; 2013.

10. RSUP Dr. M. Djamil Padang. Data pasien lost follow up Oktober 2016 sampai dengan Maret 2017 poliklinik VCT. Padang; 2017.

11. Hansana V, Sanchaisuriya P, Durham J, Sychareun

$\mathrm{V}$, Chaleunvong $\mathrm{K}$, Boonyaleepun $\mathrm{S}$, et al. Adherence to antiretroviral therapy (ART) among people living with HIV (PLHIV): A cross sectional 
survey to measure in Lao PDR. BMC Public Health. 2013;13;617.

12. Achappa B, Madi D, Bhaskaran U, Ramapuram JT,. Rao S, Mahalingam S. Adherence to antiretroviral therapy among people living wit HIV. North American Journal of Medical Sciences. March 2013;5(3):220-3.

13. Horne R, Weinman K, Barber N, Elliot R, Morgan M. Report for the national co-ordinating centre for NHS service delivery and organisation R \& D (NCCSDO). London School of Hygine \& tropical medicine; 2005 Desember.

14. Chesney MA, Ickovics JR, Chambers DB, Gifford AL, Neidig J, Zwickl B, Wu AW. Self-reported adherence to antiretroviral medications among participants in HIV clinical trials: The AACTG adherence instruments. AIDS Care. 2000 Jun;12(3):255-66.

15. Bandura A. Self efficacy the exercise of control. New York: WH Freeman and Company; $1997 .$. Chapter 4 hlm.116.

16. Taylor SE. Health psychology. New York: Mc Graw Hill education; 2018.hlm.465-7.

17. Huang L, Li L, Zhang Y, Li H, Li X, Wang H. Selfefficacy, medication adherence, and quality of life among people living with HIV in Hunan Province of China: A questionnaire survey. J Assoc Nurses AIDS Care. 2013;24(2):145-53.

18. Khotimah S, Hargono S, Fatah MZ. Self efficacy and adherence to antiretroviral (ARV) drug therapy among people living with HIV-AIDS (PLWHA). IJPHCS. Oktober 2018;5(5):81-7.

19. Lumbanbatu VV, Maas LT, Lubis Al. Faktor-faktor yang berhubungan dengan kepatuhan ODHA (orang dengan HIVIAIDS) dalam menjalani terapi antiretroviral di RSU. Dr. Pringadi Medan [artikel ilmiah]. Medan: Fakultas Kesehatan Masyarakat, Universitas Sumatera Utara; 2012.

20. Smet, Bart. Psikologi Kesehatan. Jakarta. PT Gramedia Widiasarana Indonesia; 1994.

21. Damulira C, Mukasa MN, Byansi W, Nabunya $P$, Kivumbi A, Namatovu $\mathrm{F}$, et al. Examining the relationship of social support and family cohesion on ART adherence among HIV-positive adolescents in southern Uganda: baseline findings. Vulnerable Children and Youth Studies. 2019;14(2):1-10.

22. George S, McGrath N. Social support, disclosure and stigma and the association with non-adherence in the six months after antiretroviral therapy initiation among a cohort of HIV-positive adults in rural KwaZulu-Natal, South Africa. AIDS Care. 2019; 31 (7):875-84.

23. Renju J, Moshabela M, McLean E, Ddaaki W, Skovdal M, Odongo $\mathrm{F}$, et al. Side effects' are 'central effects' that challenge retention in HIV treatment programmes in six sub-Saharan African countries: a multicountry qualitative study. Sex Transm Infect. 2017;0:1-5. 